\title{
Diplomasi Sains Komunitas Epistemik Jerman Dalam Meningkatkan Pembangunan Kolombia
}

Dzikiara Pesona Sadewa ${ }^{1}$

dzikiara_kiki@yahoo.co.id ${ }^{1}$

${ }^{1}$ Program Studi Magister Ilmu Politik, Konsentrasi Hubungan Internasional, Universitas Padjadjaran, Jln. Bukit Dago Utara No. 25, Bandung, 40135, Indonesia

\begin{abstract}
Abstrak
Artikel ini membahas bagaimana upaya diplomasi sains yang dilakukan Komunitas Epistemik Jerman dalam meningkatkan pembangunan Kolombia. Komunitas Epistemik menjadi penghubung kedua negara dengan harapan dapat memberikan kontribusi terhadap suatu kebijakan negara melalui ilmu pengetahuan dalam menangani berbagai isu masalah lokal maupun global serta dapat juga berkontribusi terhadap pembangunan Kolombia. Dengan menggunakan metode penelitian deskriptif kualitatif beserta konsep komunitas epistemik dan diplomasi sains, penelitian ini menghasilkan temuan bahwa Diplomasi Sains yang dilakukan oleh Komunitas Epistemik Jerman dalam meningkatkan pembangunan di Kolombia mewujud dalam bentuk upaya meningkatkan kerjasama akademis, mendukung pelaksanaan kegiatan akademis dalam instansi pemerintah, dan menyususn rekomendasi terhadap pengembangan berbagai aspek ilmu pengetahuan di sektor penelitian terkait kebijakan pembangunan.
\end{abstract}

Kata Kunci : Kolombia, Jerman, Komunitas Epistemik, Diplomasi Sains

\begin{abstract}
This article discusses how the scientific diplomacy efforts undertaken by the German Epistemic Community in promoting Colombian development. The Epistemic Community is the liaison between the two countries in the hope of being able to contribute to a country's policy through science in dealing with various local and global issues and can also contribute to the development of Colombia. By using descriptive qualitative research methods along with the concept of epistemic community and scientific diplomacy, this study produced findings that the Science Diplomacy carried out by the German Epistemic Community in promoting development in Colombia manifested itself in the form of efforts to improve academic collaboration, support the implementation of academic activities within government agencies, and continue recommendations for the development of various aspects of science in the research sector related to development policy.
\end{abstract}

Keywords : Colombia, Germany, Epistemic Communities, Science Diplomacy

\section{Pendahuluan}

Hubungan internasional merupakan salah satu studi yang mempelajari mengenai berbagai interaksi lintas negara yang dilakukan oleh para pelaku yang merupakan state-actor maupun non-state actor. Kompleksitas hubungan internasional telah menjadi alasan kuat untuk dapat mempelajari hubungan-hubungan antar negara sejak akhir perang dunia kedua. Kompleksitas ini disebabkan oleh multiplikasi pelaku-pelaku di bidang hubungan internasional,di antaranya adalah aktor negara-negara bangsa (Nation-State), lembaga-lembaga internasional, dan pelaku perorangan atau individu (Sitepu, 2011, hal. 5-6).Hal tersebut pada akhirnya menimbulkan perubahan dan mengalami perkembangan cukup pesat sehingga pada akhirnya state actor maupun non state actor dari ilmu hubungan internasonal telah memiliki banyak arti karena telah menyangkut semua berbagai aspek internasional dalam kehidupan sosial yang artinya bahwa semua negara dapat mempengaruhi 
tingkah laku yang telah terjadi atau dapat juga terpengaruhi dari tingkah laku manusia di negara lain. Selain itu juga hubungan internasional kini banyak di terapkan oleh negara negara di dunia demi mencapai nation interest melalui kerjasama regional.

Kolombia merupakan negara berkembang yang baru mencapai kemerdekaannya dari negara Spanyol pada tahun 1819, negara ini mulai melakukan aktivitasnya dalam membangun pemulihan dari berbagai sektor mulai dari infrastruktur, sumber daya manusia (SDM) serta pembangunan sistem politik di negaranya. Namun di sisi lain negara ini memiliki permasalahan diantaranya adalah negara ini masih minim dalam memiliki tenaga para ahli di kalangan profesional mulai dari kalangan ahli medis,ahli teknologi. hingga para pakar akademisi, sehingga negara ini mula gencar gencarnya melakukan pembangunan dalam peningkatan SDM di negaranya dengan melakukan pertukaran pelajar di luar negeri dan juga mulai memfokuskan peningkatan di negaranya melalui temuan dan keahlian di bidang pengetahuan melalui riset dengan harapan agar dapat ikut berkontribusi dalam membangun perekonomian di Kolombia (Daheshpour \& Herbert, 2018).

Jerman menjadi salah satu negara yang dipilih oleh Kolombia karena negara ini maju di bidang akademik dan riset yang pada akhirnya membuat ketertarikan Kolombia untuk menjalin hubungan lebih lanjut dengan Jerman. Pada dasarnya kedua negara ini sudah menjalin hubungan yang baik dengan cukup lama, mulai dari kerjasama ekonomi seperti bisnis, pertukaran pelajar, kebudayaan, serta sama sama mendukung perdamaian. Selain itu juga Jerman mulai berencana membangun prioritas pembangunan ekonomi terhadap Kolombia mulai dari peningkatan sumber daya manusia, pembangunan infrastruktur, kesehatan maupun penemuan ilmu pengetahuan baru untuk pembangunan di kolombia melalui berbagai riset yang di kembangkannya. Kolombia dan Jerman untuk saat ini juga mulai berkolaborasi dan memperluas kerjasamanya dengan mengedepankan penelitian mulai dari berbagai masalah isu non tradisional seperti perubahan iklim, kesehatan, perdamian dan keamanan regional. Sehingga pada akhirnya kedua negara ini juga mulai melibatkan berbagai kalangan seperti masyarakat sipil, organisasi internasional, individu, dan juga melibatkan para kaum Komunitas Epistemik (German Federal Foreign Office, 2017).

Komunitas Epistemik merupakan jaringan profesional yang memiliki keahlian dan kompetensi dalam memberikan berbagai ilmu pengetahuan yang relevan melalui berbagai penelitiannya sehingga melalui temuannya maka diharapakan dapat bermanfaat untuk dapat memberikan saran pengetahuan terhadap suatu kebijakan negara dalam menangani berbagai isu masalah lokal maupun global yang pada akhirnya memberikan pengaruhnya dalam membantu pembangunan suatu negara melalui penelitan yang telah dilakukan. Oleh karena itulah Komunitas Epistemik ini merupakan aktor non state yang sangat berpengaruh terhadap kelangsungan suatu negara.

Banyak penelitian yang telah dilakukan yang melibatkan Komunitas Epistemik dalam kelangsungan pembangunan negara ataupun memberikan hasil pemikiran tentang kebijakan yang dikeluarkan sebagai solusi terhadap permasalahan suatu negara. salah satunya adalah penelitian yang ditulis oleh Alex Balch yang berjudul Labour and Epistemic Communities: The Case of 'Managed Migration' in the UK di dalam penelitian ini di tulis bagaimana Komunitas Epistemik dapat memberikan dampak perubahan terhadap kebijakan inggris terhadap isu migrasi dan tenaga kerja di inggris pada tahun 2000 (Balch, 2009). 
Penelitian lainnya di tulis oleh Jolyon Howorth yang berjudul Discourse, Ideas, and Epistemic Communities in European Security and Defence Policy di dalam penelitian ini membahas bagaimana Komunitas Epistemik ini ikut terlibat dan memberikan ide baru terhadap kebijakan keamanan dan pertahanan di Eropa karena mengalami transisi dari perang dingin di Eropa. Dimana muncul berbagai kebijakan baru salah satunya adalah dibentuknya organisasi internasional seperti North Atlantic Treaty Organization (NATO) sebagai aktor kemanan yang dominan di Eropa dimana European Security and Defence Policy (ESDP) ini dianggap sebagai tantangan di pertengahan 1990-an. Ketika itu para elit epsitemik juga ikut terlibat dalam memberikan kontribusi pemikirannya dalam memberikan kebijakan terkait dengan keamanan di Eropa (Howorth, 2006).

Penelitian yang terakhir adalah penelitian yang di tulis oleh Derrick Cogburn yang berjudul Partners or Pawns?: The Impact of Elite Decision-Making and Epistemic Communities in Global Information Policy on Developing Countries and Transnational Civil Society. Di dalam penelitian ini membahas eksplorasi proses institusional yang kompleks yang terdiri dari global tata kelola infrastruktur cbyer dan apa dampaknya terhadap rezim elit dalam proses pembentukan negara berkembang dan organisasi masyarakat sipil transnasional. Di dalam penelitian ini telah di temukan bahwa aktor-aktor kebijakan dari negara-negara berkembang dan organisasi masyarakat sipil telah kurang efektif dibandingkan aktor lain dalam mempengaruhi proses ini. Sehingga di perlukan peran dari Komunitas Epistemik yang dilakukan melalui penelitian di masa depan tentang penggunaan 1CT untuk memperkuat partisipasi efektif negara berkembang dan organisasi masyarakat sipil dalam proses transnasional (Cogburn, 2005).

Pada ketiga penelitian tersebut terdapat persamaan dalam penelitian yang akan dilakukan dimana sama sama menjelaskan bagaimana peran dari komunitas epistemik ini dapat berkontribusi dalam membangun kebijakan terhadap pembangunan suatu negara melalui hasil pemikiran dan riset yang dilakukannya.sedangkan perbedaannya adalah di dalam penelitian yang akan dilakukan terfokus terhadap peran komunitas epistemik Jerman dalam pembangunan di Kolombia melalui diplomasi sains.

Jerman dan Kolombia pada dasarnya memiliki hubungan baik sejak lama di bidang penelitian, berawal dari adanya faktor historis kunjungan Alexander von Humboldt ke wilayah-wilayah yang berada di New Granada (yang sekarang menjadi Kolombia). Ketika dulu Alexander von Humboldt telah menetap lama di Kolombia dan dia adalah seorang ilmuan yang meneliti tentang flora dan fauna, dia juga sama sama meneliti bersama para ilmuwan terkemuka lainnya seperti Jose Celestino Mutis dan Francisco José de Caldas yang pada akhirnya sejak saat itu para ilmuan Jerman menjalin hubungan baik dengan Kolombia(Wulf, 2015, hal. 77).

Kedua negara saat ini mulai mengembangkan di dalam bidang pendidikan serta meningkatkan juga berbagai kapasitas melalui berbagai proyek untuk meningkatkan administrasi publik di Kolombia. Termasuk juga di bidang pelayanan publik, akuntabilitas, dan yang lainnya, hal tersebut juga tidak terlepas dari keterlibatan yang dilakukan oleh para Komunitas Epistemik dari Jerman(Roballo Lozano, 2012, hlm. 18-21), berdasarkan pemaparan di atas, maka peneliti ingin menguraikan bagaimana upaya komunitas Epistemik Jerman terhadap peningkatan pembangunan Kolombia melalui diplomasi sains. 


\section{Tinjauan Pustaka}

\section{Konsep Komunitas Epistemik}

Komunitas Epistemik merupakan jaringan yang terdiri dari berbagai kalangan profesional yang telah diakui keahlian dan kompetensinya dalam memberikan ilmu pengetahuan yang relevan melalui penelitiannya. Komunitas Epistemik ini pada dasarnya telah hadir sebagai aktor non state yang membantu negara dalam mengatasi permasalahannya. L. Lynch mendefiniskan bahwa secara umum Komunitas Epistemik terdiri dari para ilmuan sosial sebagai kelompok atau individu yang memiliki keahlian tertentu dan dapat memberikan pengaruh atas pembentukan berbagai isu kebijakan publik berdasarkan kepentingan bersama (Lynch, 2003) Selain itu juga menurut Haas, Komunitas Epistemik ini terdiri dari para profesional dari berbagai ilmu dan latar belakang yang berbeda sehingga mereka saling mengisi satu sama lain. Komunitas Epistemik ini dapat terbentuk karena memiliki berbagai kesamaan diantaranya dalah sebagai berikut:

1) Memiliki seperangkat norma dan prinsip bersama dalam memberikan dasar pemikirannya untuk melakukan aksi sosial terhadap masyarakat.

2) Memiliki sebuah keyakinan dengan melihat sebab- akibat yang telah dilakukan bersama dengan menganalisis berbagai praktiknya untuk ikut berkontibusi terhadap masalah utama dan menjelaskan hasil yang di dapat

3) Membagi berbagai validitas yang di dapat dalam ilmu pengetahuan di berbagai bidang dari masing masing keahlian mereka.

4) Memiliki berbagi kebijakan umum terkait praktik dalam mengatasi masalah jalan keluar untuk dapat meyakinkan terhadap masyarakat bahwa kesejahteraan manusia dapat ditingkatkan melalui ilmu pengetahuan (Haas, 1992, hal. 3).

Salah satu pendekatan Komunitas Epistemik adalah menggunakan Epistemic Frame Theory dengan menjelaskan model cara beripikir serta bertindak di dalam komunitasnya melalui praktik, yang artinya adalah praktik di sini merupakan praktik dengan adanya keterlibatan dari kelompok yang dapat melakukan pendekatan umum secara bersama sama dalam menyelidiki dan memecahkan beberapa masalah dengan cara menggunakan pengetahuan dan keterampilan. Hal tersebut dikarenakan pengetahuan dan keterampilan terdiri dari nilai nilai yang dapat memadu bagaimana cara yang harus digunakan untuk memproses dan mengambil berbagai keputusan. dengan cara berbicara, menulis,membaca, aksi, interaksi, kepercayaan, nilai dan perasaan dan menggunakan berbagai object seperti gambar, alat dan teknologi (Gee, 1999 :719).

Secara singkat, menurut Shaffer epistemic frame theory pada dasarnya menjelaskan mengenai bagaimana cara berpikir dan bertindak dan posisi sebuah komunitas praktisi hingga menjadi sebuah kelompok epistemik Shaffer juga menjelaskan bahwa Kelompok Epistemik dibuat saat para eksekutif nasional bertujuan untuk mencapai koordinasi kebijakan internasional dimana dalam perumusannya bermunculan ketidakpastian dan para pembuat keputusan membutuhkan intepretasi dari situasi tersebut dan pada saat itu juga sebuah Komunitas Epistemic dibutuhkan, (Shaffer, 2011). 


\section{Diplomasi Sains}

Hubungan internasional, ruang lingkupnya saat ini sangatlah semakin kompleks dimana saat ini keterlibatan hubungan negara terkadang juga menghubungkan antara sains dan diplomatik, hal tersebut diilakukan ntuk membangun jembatan antar negara agar terbentuknya produktifitas dalam mengembangkan keilmiahan di tingkat internasional antara aktor dalam sistem. Royal Society (2010) di London berpendapat bahwa orang orang yang terlibat dalam kegiatan-kegiatan ini adalah memiliki potensi dan nilai yang luar biasa dari diplomasi sains yang terletak di dalamnya. potensi tersebut dirancang dan diterapkan melalui solusi untuk tantangan internasional yang bersifat ilmiah dengan melalui pendekatan teknologi, karena beberapa masalah melampaui batas-batas nasional, dan tidak ada negara yang bisa menyelesaikannya sendiri. Kegiatan yang terkait dengan Diplomasi Sains biasanya telah digunakan oleh negara maju sebagai sarana kerjasama teknis. Namun demikian, konsep diplomasi sains melampaui hal tersebut dan ilmu sains mengalami perkembangan yang pada akhirnya hal tersebut dapat memberikan sumbangan pengetahuan dan kebijakan dalam cara ilmiah untuk menganalisa permasalahan suatu negara.

Menurut Vaughan C. Turekian, dijelaskan bahwa dengan melalui Diplomasi Sains dapat Menjembatani Budaya dan Mendukung dalam pengembangan serta menjadi solusi permasalahan yang di alami suatu negara.Sehingga Diplomasi Sains ini dapat ikut berkontribusi terhadap pemecahan suatu masalah. Selain itu menurut Vaugham C Tuerkian dijelaskan bahwa Diplomasi Sains dapat dikatakan berjalan dengan lancar jika memiliki instrumen dibawah ini diantaranya adalah:

1) adanya Expression, ekspresi yang di maksud di sini adalah harus ada dukungan ilmiah dan izin dari berbagai negara untuk mengekspresikan kekuatan atau pengaruhnya terhadap nasional di bidang tertentu.

2) adanya Equipment, yang dimana equipment di sini harus dapat melengkapi berjalannya sains diplomasi, hal tersebut tentu saja harus ada dukungnya dari Kementerian Luar Negeri suatu negara untuk menangani masalah-masalah teknis contohnya adalah menangani; isu-isu yang terkait dengan energi, kesehatan, dan keanekaragaman hayati, di antara topik-topik lainnya.

3) adanya Enhancement, yaitu meningkatkan hubungan bilateral dan multilateral antar negara; contoh adalah hubungan lebih lanjut dalam pengembangan antara China dan AS di bidang sains dan teknologi.

Komunitas Epistemik Jerman menjadi salah satu komunitas yang terdiri dari para ahli yang dapat berkontribusi terhadap peningkatan di Kolombia, Komunitas Epistemik Jerman ini terdiri dari berbagai bidang ahli, mulai dari ahli pendidikan,kesehatan,ekonomi dan yang lainnya yang dapat di anggap dapat membantu Kolombia dimana kedua negara dapat menjalin hubungan dan mulai adanya upaya lebih lanjut dalam mengembangkan pengetahuan terutama di dalam bidang riset.

\section{Metode Penelitian}

Penelitian ini memakai desain penelitian kualitatif, definisi penelitian kualitatif menurut Cresswell adalah metode untuk mengeksplorasi dan memahami 
makna oleh sejumlah individu atau seorang individu yang berkaitan dengan masalah pada ranah ilmu sosial selain itu penelitian kualitatif juga berguna untuk mengetahui kedalaman suatu fenomena. Penelitian kualitatif mempunyai beberapa jenis menurut Creswell, beberapa diantara jenis tersebut adalah studi kasus fenomenologi, grounded theory, studi kasus, deskriptif dan eksperimen (Creswell, 1994). Penelitian ini memakai desain penelitian deskriptif kualitatif karena tujuan dari penelitian ini untuk melihat upaya Komunitas Epistemik dalam meningkatkan pembangunan negara.

\section{Hasil Penelitian}

\section{Gambaran Umum Perekonomian Kolombia}

Kolombia merupakan salah satu negara yang telah mencapai kemerdekaannya dari Spanyol pada tahun 1819, dan negara itu diakui secara resmi oleh Amerika Serikat berawal ketika Presiden James Monroe menerima kunjungan dari seorang perwakilan diplomatik Kolombia di Washington. dengan melakukan misi diplomatik Kolombia terhadap Amerika Serikat. Saat itu Kolombia dikenal sebagai bagian dari new Granada yang mencakup wilayah Kolombia, Ekuador, Panama, dan Venezuela modern. negara ini resmi menjadi bagian dari Amerika Serikat pada tahun 1863, dan mengubah namanya menjadi Republik Kolombia pada tahun 1886 hal tersebut diikuti juga dengan Panama yang ikut terpisah dari Kolombia pada tahun 1903(United states Departement Of state, 2018) Kolombia memiliki sumber daya alam yang melimpah dikarenakan memiliki cadangan minyak yang besar dan merupakan produsen utama emas, perak, platinum, dan batubara negara ini juga memiliki budayanya yang beragam karena berisikan penduduk asli dari India, Spanyol, dan Afrika.

Tetapi hal tersebut telah itu dirusak oleh konflik yang terjadi selama puluhan tahun yang telah melibatkan kelompok-kelompok bersenjata yang pada akhirnya sering kali menimbulkan pelanggaran HAM yang berat. Sejak tahun 2002, negara ini mulai memfokuskan terhadap peningkatan keamanannya dan juga terhadap pembangunan ekonominya (BBC, 2018) Dalam tahap pembangunannya Kolombia memiliki unggulan utama yaitu sumber daya alam yang melimpah menempatkan Kolombia menjadi salah satu negara di Amerika latin dengan pertumbuhan ekonomi kedua terbesar dan negara ini juga saat ini telah di anggap menjadi sebagai negara pintu masuk ke pasar Amerika Latin (Mahendra, 2015).

Negara ini tumbuh semakin cepat dan menghasilkan PDB terbesar dengan urutan ke ketiga di Amerika Selatan (total perkiraan \$ 322 miliar, 2011) dan Kolombia juga menjadi kekuatan ekonomi yang kuat di wilayah tersebut. hal tersebut di sebabkan adanya kepercayaan investor dan hubungan komersial dengan ekonomi utama dunia sedang meningkat. Pada akhirnya para Investasi asing menjadi sangat meningkat lima kali lipat dan ekspor telah meningkat empat kali lipat sejak tahun 2000. Ekonomi Kolombia telah tumbuh lebih cepat daripada rata-rata Amerika Latin, dan negara ini dengan cepat menjadi salah satu negara dengan ekonomi berkembang terkemuka di dunia. Bahkan, beberapa ekonom memasukkannya negara ini ke dalam kelas ekonomi baru yang sedang tumbuh yang dianggap memiliki prospek tinggi untuk pertumbuhan dalam beberapa dekade mendatang (Embbasy of Colombia, 2018), namun kenyataannya adalah walaupun negara ini memiliki percepatan ekonomi yang cepat jika di bandingkan dengan negara di wilayah Amerika Latin 
lainnya, namun secara ekonomi jika di lihat dari tahun ke tahun mengalami peningkatan dan penurunan yang menyebabkan adanya ketidakstabilan.

Ketidakstabilan ekonomi di sini adalah disebabkan oleh adanya penurunan dan kenaikan investasi di beberapa sektor, selain itu juga dengan arus globalisasi yang cepat menjadikan persaingan semakin kompelks yang membuat Kolombia harus merombak berbagai kebijakan untuk menaikan pertumbuhan ekonominya. Oleh karena itulah Kolombia saat ini mulai bergegas dalam melakukan pemulihan ekonominya agar negara ini dapat menciptakan kestabilan di sektor ekonomi dengan melakukan kerjasama dengan negara lain untuk dapat memaksimalkan pemanfaatan berbagai potensi yang dimilikinya. Selain itu juga saat ini Kolombia mulai gencar gencarnya melakukan pertukaran pelajar ke negara lain dengan tujuan agar mereka yang melakukan pertukaran tersebut dapat ikut berkontribusi dalam pembangunan ekonomi di Kolombia dengan hasil penelitian dan riset yang telah dilakukannya, dikarenakan di Kolombia sendiri sedang meningkatkan kapasitas dan peningkatan SDM di negaranya dengan tujuan untuk dapat menaikan pertumbuhan ekonomi melalui kebijakan yang di dapat dari para ahli profesional

\section{Kerjasama Jerman dan Kolombia}

Kolombia dan Jerman pada dasarnya sudah menjalin hubungan diplomatik pada tahun 1882. Hubungan politik bilateral telah menguat sejak awal 2007, memperoleh momentum yang meningkat melalui berbagai kunjungan tingkat tinggi di kedua negara dan kedua negara juga mulai melakukan kerjasama di bidang perdaganga dalam kunjungan tingkat tinggi ini selalu melibatkan partisipasi pengusaha, yang telah melakukan berbagai agenda tentang hal-hal yang berkaitan dengan perdagangan dan investasi. Pada bulan Maret 2009, Menteri Federal Pendidikan dan Penelitian, Profesor Annette Schavan mengunjungi Kolombia, untuk mengeksplorasi kemungkinan kerja sama di bidang-bidang ini dan sejumlah anggota Parlemen Jerman, serta perwakilan dari lembaga dan perusahaan Jerman juga turut hadir di Kolombia (Cancilleria da Colombia, 2018).

Kedua negara ini mulai membangun kerjasama di bidang seperti ekonomi, politik, dan pendidikan. Kedua negara saat ini sepakat untuk menjalin keterikatan khususnya di bidang science .Hubungan kedua negara ini sangatlah baik dan mengalami perkembangan yang cukup signifkan terutama di bidang pendidikan. Dikarenakan kedua negara percaya melalui pendidikan dan riset yang dilakukan dapat meningkatkan pembangunan suatu negara. Hal tersebut sudah terjalin lama ketika adanya faktor history kedua negara yang berawal dari adanya kunjungan Alexander von Humboldt ilmuan asal Jerman berkunjung ke wilayah-wilayah New Granada (sekarang Kolombia). Para Ilmuan melakukan penelitian tentang masalah flora dan fauna bersama dengan Jose Celestino Mutis dan Francisco José de Caldas yang pada akhirnya telah meningkatkan hubungan baik di kedua negara sampai dengan saat ini (Wulf, 2015, hal. 77).

Hubungan budaya antara kedua negara juga didasarkan pada tradisi lama yang bahkan kembali ke zaman Ilmuwan Alam Alexander von Humboldt, penting untuk menyoroti kerja sama penting yang diberikan oleh Goethe Institute di Bogota, yang baru-baru ini membuka fasilitas baru (2011), serta Institut Kebudayaan Jerman di Medellin, Cali dan Cartagena. Sekolah-sekolah Jerman di Bogota dan juga Medellin, Cali, Barranquilla dan Leridan yang berkontribusi signifikan terhadap 
hubungan budaya dalam mengajar bahasa dan budaya Jerman dan membangun ikatan penting antara kedua negara. Pameran dagang ExpoKolumbien juga di adakan di Berlin untuk mempromosikan serta memperkenalkan berbagai aspek budaya, ekonomi, dan pendidikan Kolombia (Cancilleria da Colombia, 2018).

Pada tanggal 13 April 2011 Persiden Santos dari Kolombia melakukan kunjungannya ke Berlin untuk memperluas kerjasma dan kembali memperkuat hubungannya dengan Jerman, kunjungannya tersebu terdiri dari perjanjian dan kerjasama sebagai berikut:

1. Pertukaran Notes merupakan kesepakatan tentang penghapusan persyaratan visa bagi pemegang paspor diplomatik dan resmi.

2. Perjanjian untuk perlindungan timbal balik dari karya sastra dan artistik.

3. Perjanjian tentang kesepakatan budaya.

4. Kesepakatan umum tentang kerja sama teknis.

5. Perjanjian tentang transportasi udara.

6. Perjanjian untuk pembuatan studi dan dana para ahli

7. Nota kesepahaman untuk pembentukan konsultasi politik.

8. kerja sama di bidang pendidikan, sains, penelitian dan inovasi.

Jerman juga merupakan salah satu negara yang memiliki pertumbuhan ekonomi yang diperhitungkan di tataran internasional dan telah melakukan berbagai aktivitas dengan mendukung kebijakan luar negerinya yang berkaitan dengan sains dan teknologi. Jerman juga di kenal sebagai alat pembangunan khususnya di dalam bidang pendidikan oleh karena itulah di dalam perjanjian atau kerjasama tersebut Kolombia mulai mementingkan kerjasamanya terutama di bidang pendidikan karena Jerman dikenal dengan "Land of Ideas" di tingkat internasional Jerman lah menggunakan unsur diplomasi sains melalui strategi komprehensif yang dipimpin dengan penelitian ilmiah yang mencakup hubungan politik, ekonomi, dan budaya. Perjanjian Kerjasama Pendidikan keuda negara antara lain adalah

1. ICETEX (Colombian Institute for Education Credit and Technical Studies Abroad) dan DAAD (German Academic Exchange Service)

2. Kerangka Perjanjian untuk Kerjasama Internasional antara SENA ((National Learning Service) dan BIBB (Federal Institute for Vocational Education and Training).

3. Nota Kesepahaman untuk Kerjasama Jerman-Kolombia antara Deutsche Forschungsgemeinschaft e.V (DFG) dari Jerman dan COLCIENCIAS (Administrative Department of Science, Technology and Innovation) dari Kolombia.

4. Kerjasama Pendidikan, Ilmu Pengetahuan, Penelitian dan Inovasi antara Pemerintah Republik Federal Jerman dan Pemerintah Republik Kolombia.

Salah satu kerjasama dalam penelitian ilmiah yang sudah dilakukan antara Jerman dan Kolombia diantaranya adalah penelitian dalam menciptakan perusahaan penerbangan komersial pertama di Kolombia 1919 yaitu Sociedad Colombo-Alemana de Transportes Aéreos (SCADTA). Selain itu juga untuk saat ini kedua negara mulai melakukan kerjasama dalam pengembangan infrastruktur pembangunan jembatan, jalan, dan rel kereta api (Weber, 2011). 


\section{Upaya Komunitas Epistemik Jerman dalam Meningkatkan Pembangunan Kolombia Melalui Diplomasi Sains}

Kedua negara mulai mengembangkan diplomasi sains untuk meningkatkan pembangunan melalui berbagai penelitian. Salah satu faktor yang membuat pertumbuhan ekonomi Jerman saat ini di pertimbangkan di dunia internasional. tidak terlepas dari peran Epistemic Communities yang terlibat di dalamnya. para ahli dari Komunitas Epistemik ini telah mendapatan keterbukaan untuk menyatakan pendapat dari pemerintah Jerman untuk ikut menciptakan serta mengembangkan pembangunan melalui riset dalam penerapannya Seperti yang dikatakan Peter Haas bahwa Komunitas Epistemik umumnya muncul di negara-negara dengan kapasitas penelitian yang baik dimana hal tersebut dapat muncul ketika adanya dukungan dari pemerintah di mana para ilmuwan dapat menikmati otonomi dari negaranya yang artinya adalah kegiatan yang dilakukan oleh para ahli ini berkaitan dengan adanya aktivitas dalam kelangsungan kerjasama dari kedua negara terutama di dalam Diplomasi Sains, karena dengan adanya kesamaan dan dukungan dari ide ide yang di berikan dari Komunitas Epistemik terhadap negara maka dapat menciptakan sebuah strategi soft power Jerman terhadap Kolombia yang menjadikan sarana untuk dapat menjangkau subjek penelitian. Hal tersebut mencakup seperti pemanfaatan sumber daya alam, pembangunan ekonomi negara dan dapat juga ikut juga mengembangkan manusia dengan kapasitas tinggi di bidang pengetahuan (Aranzales, Bonilla; , Jhon Kelly, 2017, hal. 69)

Komunitas Epistemik yang pertama adalah German Academic Exchange Service atau Deutscher Akademischer Austauschdienst (DAAD) yang merupakan organisasi yang bergerak di bidang institusi pendidikan dimana organisasi ini telah tersebar di berbagai negara di dunia dan oganisasi ini berupaya untuk meningkatkan kerjasama akademis di seluruh dunia dengan cara meningkatkan kerjasama terutama melalui pertukaran mahasiswa, akademisi dan para ilmuwan. DAAD juga melakukan kerjasamanya dengan Kementerian Luar Negeri Jerman setiap tahunnya yang menjadikan organisasi ini sebagai penyumbang dana terbesar di dunia dalam bidang akademik dan penelitian. Organsiasi ini juga bertujuan untuk ikut membantu negara negara berkembang dalam mempromosikan bagaimana sistem pendidikan di Jerman, serta ikut juga membantu pemerintah dalam mendukung studi dan program bahasa Jerman. Organisasi ini memiliki program beasiswa internasional untuk para seniman untuk dapat mengembangkan bakat dan karyanya (DAAD 2018). Dalam mendukung melalui perwakilannya di Kolombia, DAAD tidak hanya memberikan beasiswa dan pertukaran pelajar saja namun juga ikut mendukung dalam kerjasama melalui berbagai proyek riset dalam bidang pengetahuan terutama dalam bidang perdamaian dan ilmu kelautan dengan cara menciptakan kolaborasi penelitian dengan Kolombia. Selain itu juga DAAD memainkan peran sebagai negosiator perwakilan akademik dan politik Jerman yang dijadikan sebagai sarana untuk penelitian di bidang perdamian dan di bidang kelautan dengan cara berkolaborasi dengan Kolombia dan bekerjasama antar institusi dari kedua negara diantaranya adalah oleh German-Colombian Peace Institute (CAPAZ) dan Corporation Center Of Excellence In Marine Sciences (CEMarin) (Alumni Portal deutschland, 2018) berikut ini yang merupakan kolaborasi riset yang dilakukan kedua negara diantaranya adalah: 


\section{German-Colombian Peace Institute (CAPAZ)}

German-Colombian Peace Institute atau yang di kenal dengan nama CAPAZ merupakan kumpulan dari Komunitas Epsitemik di bidang akademik yang terdiri dari kerjasama yang di jalin oleh Kolmbia dan Jerman dengan tujuan untuk menciptakan perdamaian, dimana negara Kolombia ini memiliki tantangan yang kompleks mulai dari masalah sosial, politik dan ekonomi, dengan dibentuknya organisasi ini diharapkan dapat menciptakan pembangunan perdamaian yang stabil di Kolombia, CAPAZ dibentuk juga sebagai proyeksi dan memberikan pengetahuan terhadap masyarakat di bidang perdamaian. ,historis, perdamaian teritorial, keadilan transisional dan konflik dengan cara memperkuat dialog dan memberikan pengetahuan bersama antara akademi dan sektor publik antara pusat maupun daerah. serta melibatkan juga penelitian terhadap masalah yang menghambat perdamaian, (DAAD Colombia, 2018).

2. Corporation Center of Excellence In Marine Sciences (CEMarin)

CEMarin dibentuk atas kerjama yang dilakukan oleh Kementerian Luar Negeri Jerman, DAAD, 5 universitas Kolombia dan 1 dari universitas Jerman. CEMarin dibentuk menjadi kolabrasi ilmiah di bidang kelautan yang menjadikan organiasi ini menjadi salah satu dari empat pusat unggulan penelitian ilmu kelautan di seluruh dunia. CEMarin menjadi harapan dalam mengatasi masalah kompleks di bidang kelautan dengan menawarkan solusi praktis untuk masalah perlindungan dan keberlanjutan keanekaragaman hayati laut dan sumber daya laut.

Komunitas Epistemik Jerman yang kedua adalah Max Planck Institute (MPI) dimana institusi ini terdiri dari para ilmuan yang meneliti penelitian medis dasar dalam ilmu saraf dan onkologi. Kegiatan penelitian mencakup berbagai topik, mulai dari analisis molekuler dasar proses neuronal hingga studi klinis tentang terapi baru terhadap gangguan neurologis dan psikiatrik pada pasien. Tujuan utama dari semua penelitian ini adalah untuk memahami proses molekuler dan seluler dasar dalam fungsi otak, menganalisis disfungsi patologisnya pada penyakit psikiatrik dan neurologis, dan pada akhirnya mengembangkan terapi baru untuk gangguan penyakit tersebut, .selain itu juga banyak temuan para ilmuan yang mendasar dari penyakit kejiwaan seperti autisme dan skizofrenia gangguan neurologis seperti multiple sclerosis dan stroke, atau kanker.

Sebagai contoh, para ilmuwan mereka mulai mengembangkan solusi alternatif dalam penyembuhan penyakit tersebut dan mencari penemuan baru dalam mempelajari perkembangan otak dan dasar molekul dari transmisi sinyal antara sel-sel saraf. Dan berfokus terhadap fungsi saluran protein dalam membran sel dan bagaimana perannya dalam penyembuhan dari perkembangan kanker (MPI, 2018). Institusi ini juga bekerjasama dengan Max Planck Society dimana intitusi ini merupakan salah satu institusi riset yang sukses di Jerman.

Sejak didirikan pada tahun 1948, kurang lebih sekitar 18 mendapatkan pemenang Nobel dari jajaran ilmuwannya yang pada akhrinya menempatkannya setara dengan lembaga penelitian terbaik dan paling bergengsi di seluruh dunia dan lebih dari 15.000 publikasi setiap tahun di jurnal-jurnal ilmiah yang terkenal di lingkup internasional Max Planck saat ini 86 melakukan penelitian dasar dalam melayani masyarakat umum dalam ilmu alam, ilmu kehidupan, ilmu sosial, dan 
humaniora. Max Planck Institutes fokus pada bidang penelitian yang sangat inovatif, atau yang sangat menuntut dalam hal pendanaan di bidang penelitian (MPG, 2018). Institusi ini juga bekerjasama dengan kamupus yang ada di Kolombia seperti Universidad de Antioquia, dan Universidad Nacional de Colombia, dan Colciencias (Departemen Administrasi Kolombia untuk Sains, Teknologi dan Inovasi) mereka mencoba melakukan penelitian tentang penyakit menular dan keanegaragaman hayati. Lembaga penelitian ini juga memulai proses kerja sama penelitian dengan para ilmuwan Kolombia melalui program pelatihan di Jerman ( Udea, 2018).

Komunitas Epistemik Jerman yang ketiga adalah Alexander Von Humboldth dimana organisasi ini mejadi perantara terhadap kebijakan budaya dan pendidikan asing di Jerman, organisasi ini juga didukung oleh Kementerian Luar Negeri Jerman untuk dapat mempromosikan budaya internasional dan pertukaran akademik dengan negara lain. Selain itu juga Alexander Von Humboldth menawarkan berbagai program beasiswa terhadap para ilmuan dari luar negeri untuk menyelesakan penelitian dalam waktu jangka pamjang di Jerman (Federal Ministry Of Education And Research German, 2018).

Dalam perannya terhadap Kolombia, organisasi ini juga ikut mendukung kegiatan penelitian melalui hibah yang diberikan oleh ilmuwan dari Jerman terhadap Kolombia dan mengembangkan keilmuannya dengan cara mengembangkan pengetahuannya di negara Jerman, saat ini juga para akademi yang sudah bergabung menjadi akademisi pembuatan kebijakan di Kolombia. Salah satunya adalah lembaga penelitian di dalam bidang sumber daya Biologi Alexander Von Humboldt yang ketika itu Kolmbia ikut merativikasi konvensi dari Perserikatan Bangsa-Bangsa tentang kanekaragaman hayati di tahun 1994 dan Institut Humboldt juga menghasilkan pengetahuan yang di perlukan untuk penelitian lebih lanjut dalam keanekaragaman hayati di Kolombia dalam membuat keputusan keputusannya contohnya adalah tentang pembuatan kebijakan terhadap iklim, sungai Otoy-Meta di Kolombia dan Hutan Kering Tropis di Kolombia dimana organisasi ini mengatur dalam strategi tata kelola, politik serta prundang undangan melalui pengembangan rencana dalam $\mathrm{r}$ iset (Humboldt, 2018).

Komunitas Epistemik Jerman yang terakhir adalah German Council of Science and Humanities yang merupakan badan penasehat untuk pemerintah Federal dan pemerintah negara bagian. Fungsi dari badan ini adalah mempunyai tugas dalam menyususn rekomendasi terhadap pengembangan berbagai aspek ilmu pengetahuan di sektor penelitian termasuk menyangkut lembaga lembaga ilmiah (mulai dari universitas, ilmu terapan serta lembaga penelitian dari non universitas) dalam pengembangan serta perencanaan strategis dari penilaian bidang disiplin ilmu tertentu di Jerman (German Council Of Science and Humanities, 2019). Dalam kerjasama yang dilakukan di Kolombia, institusi tersebut juga bekerjasama dengan badan penelitian lainnya seperti Deutsche Forschungsgemeinschaft (DF) dan Bundesministerium Fur Bildung Und Forschung (BMBF) dan universitas Universidad de los Andes (UNIANDES) di Kolombia, terutama di bidang sains dan teknologi, berbagai proyek saat ini sudha dilakukan dan mulai melakukan perpanjangan perjanjian kerja sama mereka untuk saling membiayai proyek penelitian Jerman-Kolombia (DFG , 2018). 


\section{Kesimpulan}

Komunitas Epistemik merupakan sebuah jaringan profesional yang bisa berupa ilmuwan hingga praktisi. Kelompok tersebut dibutuhkan oleh sebuah aktor dalam merumuskan kebijakan yang akan dibuat, hal ini diperlukan karena kebijakan yang akan dibuat menyangkut banyak faktor dan bersifat teknis. Menggunakan kelompok professional tersebut aktor yang membutuhkan akan mendapatkan masukan ilmiah yang bisa digunakan untuk mendukung kebijakan yang akan dibuat. Dalam pembuatan sebuah konvensi atau bentuk rezim lainnya yang sangat bersifat teknis membutuhkan bantuan professional tersebut karena negara atau aktor yang membuat kebijakan tersebut tidak begitu paham atau bingung terhadap kebijakan yang akan dibuat, maka dengan melakukan interaksi dengan Komunitas Epistemik ini maka terdapat pemahaman yang lebih mendalam Berdasarkan pemaparan diatas kerja sama ilmiah yang dilakukan Jerman dan Kolombia merupakan hasil dari interaksi antara para Komunitas Epistemik dan pemerintah untuk pembangunan Kolombia. Upaya diplomasi sains yang dilakukan oleh Komunitas Epistemik Jerman dalam meningkatkan pembangunan di Kolombia secara umum dilakukan dengan cara meningkatkan kerjasama akademis, mendukung pelaksanaan kegiatan akademis dalam instansi pemerintah, dan menyususn rekomendasi terhadap pengembangan berbagai aspek ilmu pengetahuan di sektor penelitian terkait kebijakan pembangunan.

\section{Referensi}

Adler, E. (1997). Seizing the Middle Ground: Constructivism in World Politics. . European Journal of International Relations.

Alexander von Humboldt (2018) Instituto de Investigación de Recursos Biológicos

Alexander von Humboldt diakses melalui http://www.humboldt.org. $\mathrm{co} / \mathrm{en} /$ institute/about-us/what-do-we-do

Alumni Portal deutschland. (2018). Colombia and Germany consolidate international research partnerships: melalui https://www.alumniportal-deutschland.org/en/science-research/news-fro m-science/international-research-partnerships-colombia-germany/

Aranzales, B. \& Kelly. J. (2017). The role of epistemic communities in science diplomacy : an Analysis of U.S and German foreign policy towards Colombia. Universidad del Rosario Colombia

Bakry. U, S, (2017). Dasar Dasar hubungan Internasional .Jakarta:Pranadamedia Group

Balch, A. (2009). Labour and Epistemic Communities:The Case of 'Managed Migration' in the UK. The British Journal of Politics and International Relations, VOL 11, 613-633.

BBC. (2018, Agustus 8) Colombia country profile: Melalui https://www.bbc.com/ news/ world-latin-america-19390026

Cancilleria de Colombia (2018) German diakses melalui https: //www. cancilleria. gov.co/en/ content/germany

Capaz (2018) Capaz Project diakses melalui https://www.instituto-capaz.org/ areas/ projects/

Cemarin (2018) Cemarin Work diakses melalui https://www.cemarin.org/en/our-work/ 
Cogburn, D. (2005). Partners or Pawns?: The Impact of Elite Decision-Making and Epistemic Communities in Global Information Policy on Developing Countries and Transnational Civil Society. Knowledge, Technology, \& Policy.

Cresswell J.(2014).Research Design Qualitative, Quantitative And Mixed,SAGE:London

DAAD (2018) The internationalisation agency diakses melalui https:// www. daad .de/der-daad/ueber-den-daad/ portrait/en/29143-the-internationalisation-agency/

DAAD Colombia (2018) Proyectos de cooperación diakses melalui https:/ /www.daad.co/es/quienes-somos/proyectos-de-cooperacion/

DFG (2018) DFG profile di akses melalui https:// www.dfg.de/ en/dfg_ profile/ mission/index.html

Embassy of Colombia Washington, DC (2008) Economy of Colombia melalui http:/ / colombiaemb.org / node/ 1328

Federal Ministry Of Education and Research (2018) Alexander Von Humboldt Foundation diakses melalui https://www.research-in-germany. org/en/ researchfunding/funding-organisations/alexander-von-humboldt-foundation.html

German Council Of Science and Humanities (2019), diakses melalui https:// rio.jrc.ec.europa.eu/en/organisations/german-council-science-and-humaniti es-wr

German Federal Foreign Office. (2017, Oktober 7melalui , dari de en aussenpolitik laenderin formati onen kolumbien-node colombia: Melalui https://www.auswaertiges-amt. de/ en/aussenpolitik /laenderin formati onen/ kolumbien-node/ colombia/22949 4\#content_1

Haas, P. (1992). Introduction: Epistemic Communities and International Policy.

Howorth, J. (2006). Discourse, Ideas, and Epistemic Communities in European Security and Defence Policy. West European Politics.

Katzenstein, P. e. (1996). The Culture of National Security: Norms and Identity in World Politics. New York: Columbia University Press.

Mahendra, D. I. (2015, September 14). Pintu Masuk Pasar Amerika Latin: melalui http://mediaindonesia.com/read/detail/19556-kolombia-sebagai-pintu-ma suk-pasar-amerika-latin

Perwita, A. B., \& Yani, Y. M. (2005). Pengantar Ilmu Hubungan Internasional. Bandung: PT Remaja Rosdakarya.

Rudy, T. M. (2003). Hubungan Internasional Kontemporer Dan Masalah - Masalah Global. Bandung: Refika Aditama.

Shaffer, D.W (2011). 2011,Epistemic Network. Analysis, Madison:USA

Sitepu, P. A. (2011). Studi Hubungan Internasional. Yogyakarta: Graha Ilmu.

Wulf, A. (2015). The Invention of Nature: Alexander von Humboldt's New World. Knopf Doubleday Publishing Group. 
MPI (2018) Max Planck Institute for Experimental Medicine diakses melalui https: //www.mpg.de/152284/experimentelle_medizin

MPG (2018) A portrait of the Max Planck Society diakses melalui https:// www. mpg.de/short-portrait

Udea (2018) UdeA-Max Planck Society research groups get underway diakses melaluihttp://www.udea.edu.co/wps/portal/udea/web/inicio/investigacio $\mathrm{n} /$ grupos-investigacion/max-planck

United states Departement Of state. (2018). Dipetik Februari 14, 2019, dari A Guide to the United States' History of Recognition, Diplomatic, and Consular Relations, by Country, since 1776: Colombia: https://history.state.gov/countries/colombia 